\title{
APPLICATION OF LINEAR PROGRAMMING FOR PROFIT MAXIMIZATION OF A HOUSING CONSTRUCTION COMPANY: A CASE STUDY OF URBANIZATION OF MILLENNIALS
}

\author{
Dr. Abhijit Pandit \\ Amity Business School \\ Amity University, Kolkata, West Bengal, India
}

\begin{abstract}
The main objective of this paper was to maximize of the profit of a Construction Company in areas of developing a Housing Society and Shopping mall by constructing three types of House (Flat) such as type A (1000 square feet), type B (1200 square feet) and type C (1500 square feet) and shops in mall of type $A$ (100 square feet), type $B$ ( 180 square feet) and type $C$ ( 300 square feet) with in constraints such as total number of House (Flat) and shops in the project, material (Concrete, Cement, sand, Glass, etc.) used for each House (Flat) and shops construction, Flooring tiles (stones) used for each House (flat) and shops construction, Colouring used for each House (Flat) and shops and available man Hours. We apply linear programming technique to maximize profit of the company.
\end{abstract}

Keywords - Linear Programming, Model, objective function, Constraints, Decision variables, Maximization.

\section{INTRODUCTION}

One of the most important branches of operation research is linear programming. Linear programming is a mathematical technique which contains the strategy of business activities to acquire an optimal solution (Dantzig et al (2006)). It is use for taking decision for optimization of problems that contain many constraints (Dorfman et al (1987)). It is used in many different areas such as in military, health systems, organization, transportation, assignment problems, industries and other real problems for maximum profit. In order to optimize usage of limited resources, the best technique is linear programming (Oladejo et al (2019)). Linear programming technique can be use in many construction plans for optimization. The process to develop a housing society is very complex problem (Wallbaum et al (2012)). Housing development business is a high competition business in construction industry (Arditi et al (2000)). The task to complete the housing construction project within budget and within limited resources is very difficult (Mahdi (2004)). The execution of housing construction project and its management is very challenging. For developing of project there are many important factors such as choice of technology, work definition, estimation of material and duration of project (Hendrickson et al (1987)). Housing construction project is very large-scale project (Kandil et al (2010)). It is used to find minimum construction cost or maximum profit for complete project with condition that total number of house, project time, available materials and number of contractor (Olawale et al (2010)). Many researchers used linear programming in construction business for optimum result such as :

(1)Connie et al.(2001) used linear programming for dormitory development plan to calculate number of rooms and area of each facility for maximum profit.

(2)Ling (2013) used linear programming technique to find optimal plan for Construction Enterprises.

(3)Ahmed (2015) used linear programming technique to find maximum profit within limited budget for a construction project.

The objective of this study is to find the maximum profit of a company in the field of development of Housing Society and Shopping Mall.

The general form of linear programming problem is Optimize

$$
\mathrm{Z}=\mathrm{c}_{1} \mathrm{w}_{1}+\mathrm{c}_{2} \mathrm{~W}_{2}+\ldots+\mathrm{c}_{\mathrm{n}} \mathrm{W}_{\mathrm{n}} \text { (objective function) }
$$

subject to the constraints 


$$
\begin{aligned}
& \mathrm{a}_{11} \mathrm{w}_{1}+\mathrm{a}_{12} \mathrm{w}_{2}+\ldots+\mathrm{a}_{1 \mathrm{n}} \mathrm{w}_{\mathrm{n}}(\leq,=, \geq) \mathrm{b}_{1} \\
& \mathrm{a}_{21} \mathrm{w}_{1}+\mathrm{a}_{22} \mathrm{w}_{2}+\ldots+\mathrm{a}_{2 \mathrm{n}} \mathrm{w}_{\mathrm{n}}(\leq,=, \geq) \mathrm{b}_{2} \\
& \mathrm{a}_{\mathrm{m} 1} \mathrm{w}_{1}+\mathrm{a}_{\mathrm{m} 2} \mathrm{w}_{2}+\ldots+\mathrm{a}_{\mathrm{mn}} \mathrm{w}_{\mathrm{n}}(\leq,=, \geq) \mathrm{b}_{\mathrm{m}}
\end{aligned}
$$

and non-negative restrictions

$$
\mathrm{w}_{\mathrm{j}} \geq 0, \quad \mathrm{j}=1,2 \ldots \mathrm{n}
$$

Where aij's, bi's and cj's are constants and wj's are variables. In the conditions given by (2) there may be any of the three signs $\leq,=, \geq$

The standard form of the linear programming problem of $n$ variables and $\mathrm{m}$ constraints can be written as follows:

Optimize

$\mathrm{z}=\mathrm{c}_{1} \mathrm{w}_{1}+\mathrm{c}_{2} \mathrm{w}_{2}+\ldots+\mathrm{c}_{\mathrm{n}} \mathrm{w}_{\mathrm{n}}+0 . \mathrm{s}_{1}+0 . \mathrm{s}_{2}+\ldots+0 . \mathrm{s}_{\mathrm{m}}$ (objective function)

subject to the constraints

$$
\begin{aligned}
& \mathrm{a}_{11} \mathrm{w}_{1}+\mathrm{a}_{12} \mathrm{w}_{2}+\ldots+\mathrm{a}_{1 \mathrm{n}} \mathrm{w}_{\mathrm{n}}+\mathrm{s}_{1}=\mathrm{b}_{1} \\
& \mathrm{a}_{21} \mathrm{w}_{1}+\mathrm{a}_{22} \mathrm{w}_{2}+\ldots+\mathrm{a}_{2 \mathrm{n}} \mathrm{w}_{\mathrm{n}}+\mathrm{s}_{2}=\mathrm{b}_{2} \\
& \left.\begin{array}{cccc}
\cdots \cdots \cdots & \cdots \cdots \cdots & \cdots \cdots \cdots \cdots & \cdots \cdots \cdots \cdots \\
\mathrm{a}_{\mathrm{m} 1} \mathrm{w}_{1}+\mathrm{a}_{\mathrm{m} 2} \mathrm{w}_{2}+\ldots+\mathrm{a}_{\mathrm{mn}} \mathrm{w}_{\mathrm{n}}+\mathrm{s}_{\mathrm{m}}=\mathrm{b}_{\mathrm{m}}
\end{array}\right\}
\end{aligned}
$$

and non-negative restrictions

$$
w_{j} \geq 0, s_{i} \geq 0, j=1,2 \ldots n, i=1,2 \ldots m
$$

Where aij's, bi's and cj's are constants and wj's and si's are variables.

Assumptions for the problems:

(i) It is assumed that the total number of House (Flat) and shops are fixed.

(ii) It is assumed that the available material, flooring tiles (stone), colouring and man hours are fixed.

(iii) It is assumed that there is a linear relationship among the variables used in the problem.

\section{PROPOSED ALGORITHM}

\section{A. Data presentation for developing a Housing Society -}

The data for this paper are assumed values. The company has following constraints: (vi) Total number of House (Flat) of type B is at least 18.

(vii) Total number of House (Flat) of type $\mathrm{C}$ is at least 10 .

Materials such as Concrete, Cement, sand etc. used are not more than 20,000 Packets. Colours used not more than 14,000 Litres. Flooring tiles (stone) used are not more than 50,000 square feet. 95,000 hours.

Total number of House (Flat) of type $\mathrm{A}$ is at most 45 .

The data for Housing Society are given in the following table:

\begin{tabular}{|c|c|c|c|c|c|}
\hline \multirow{2}{*}{$\begin{array}{c}\text { House } \\
\text { (Flat) }\end{array}$} & $\begin{array}{c}\text { Concrete } \\
\text { (in } \\
\text { packet) }\end{array}$ & $\begin{array}{c}\text { Flooring } \\
\text { tiles } \\
\text { (in square } \\
\text { feet) }\end{array}$ & $\begin{array}{c}\text { Colours } \\
\text { (in litre) }\end{array}$ & Man Hr. & $\begin{array}{c}\text { Profit } \\
\text { (Rs.) }\end{array}$ \\
\hline Type A & 150 & 700 & 20 & 1400 & 50,000 \\
\hline Type B & 180 & 850 & 24 & 1700 & 60,000 \\
\hline Type C & 210 & 1000 & 30 & 2100 & 70,000 \\
\hline
\end{tabular}

Let number of House (Flat) of type $A=w 1$

Let number of House (Flat) of type $\mathrm{B}=\mathrm{w} 2$

Let number of House (Flat) of type $\mathrm{C}=\mathrm{w} 3$

Let $\mathrm{Z}$ represent the total profit to be maximized.

The linear programming problem for the above data is given by

Maximize $Z=50000 w 1+60000 w 2+70000 w 3$

Subject to

$$
\begin{aligned}
& 150 \mathrm{w} 1+180 \mathrm{w} 2+210 \mathrm{w} 3 \leq 20,000 \\
& 700 \mathrm{w} 1+850 \mathrm{w} 2+1000 \mathrm{w} 3 \leq 50,000 \\
& 20 \mathrm{w} 1+24 \mathrm{w} 2+30 \mathrm{w} 3 \leq 14,000 \\
& 1400 \mathrm{w} 1+1700 \mathrm{w} 2+2100 \mathrm{w} 3 \leq 95,000 \\
& \mathrm{w} 1 \leq 45 \\
& \text { w2 } \geq 18 \\
& \text { w3 } \geq 10 \\
& \mathrm{w} 1, \mathrm{w} 2, \mathrm{w} 3 \geq 0
\end{aligned}
$$

Using slack and surplus variables (Arsham, H. (1997)), the problem converted to

Maximize

$\mathrm{z}=50000 \mathrm{w} 1+60000 \mathrm{w} 2+70000 \mathrm{w} 3+0 . \mathrm{s} 1+0 . \mathrm{s} 2+0 . \mathrm{s} 3+0 . \mathrm{s} 4+0 . \mathrm{s} 5+$ $0 . s 6+0.57$

Subject to

$$
\begin{array}{ll}
150 \mathrm{w} 1+180 \mathrm{w} 2+210 \mathrm{w} 3+\mathrm{s} 1 & =20,000 \\
700 \mathrm{w} 1+850 \mathrm{w} 2+1000 \mathrm{w} 3+\mathrm{s} 2 & =50,000
\end{array}
$$




$\begin{array}{lr}20 \mathrm{w} 1+24 \mathrm{w} 2+30 \mathrm{w} 3+\mathrm{s} 3 & =14,000 \\ 1400 \mathrm{w} 1+1700 \mathrm{w} 2+2100 \mathrm{w} 3+\mathrm{s} 4 & =95,000 \\ \mathrm{w} 1+\mathrm{s} 5 & =45 \\ \mathrm{w} 2-\mathrm{s} 6 & =18 \\ \mathrm{w} 3-\mathrm{s} 7 & =10 \\ \mathrm{w} 1, \mathrm{w} 2, \mathrm{w} 3, \mathrm{~s} 1, \mathrm{~s} 2, \mathrm{~s} 3, \mathrm{~s} 4, \mathrm{~s} 5, \mathrm{~s} 6, \mathrm{~s} 7 & \geq 0\end{array}$

By Appling Lingo software (Goodarzi et al (2014)) for solving the above problem, we get an optimal solution (Makowski et $\mathrm{al}(2000))$ as $\mathrm{w} 1=31, \mathrm{w} 2=18, \mathrm{w} 3=10$ and Maximum $\mathrm{Z}=$ $33,30,000$.

\section{B. Data presentation for developing a Shopping Mall -}

The data for this paper are assumed values. The company has following Constraints:

(i) Materials such as Concrete, Cement, Sand etc. used are not more than 7800 packets.

(ii) (ii) Material for Interior decoration used is more than 10000 units.

(iii) (iii)Flooring tiles (stone) used are not more than 35000 square feet.

(iv) (iv)The total man hours used is not more than 70000 hours.

(v) (v)Paint Colour used not more than 11000 litres.

(vi) (vi)Total number of shops of type $\mathrm{A}$ is at least 100 .

(vii) (vii)Total number of shops of type $B$ is at least 50.

(viii) (viii)Total number of shops of type $\mathrm{C}$ is at least 50 .

The data for Shopping mall is given in the following table:

\begin{tabular}{|c|c|c|c|c|c|c|}
\hline \multirow[b]{2}{*}{ Shops } & \multicolumn{5}{|c|}{ Material Used per Shops } & \multirow[b]{2}{*}{$\begin{array}{l}\text { Profit } \\
\text { (in } \\
\text { Rs.) }\end{array}$} \\
\hline & $\begin{array}{c}\text { Concrete } \\
\text { (in } \\
\text { packet) }\end{array}$ & $\begin{array}{l}\text { Flooring } \\
\text { tiles } \\
\text { (in } \\
\text { square } \\
\text { feet) }\end{array}$ & $\begin{array}{c}\text { Material } \\
\text { for } \\
\text { interior } \\
\text { decoration } \\
\text { (in units) }\end{array}$ & $\begin{array}{l}\text { Paint } \\
\text { Colour } \\
\text { (in litre) }\end{array}$ & $\begin{array}{c}\text { Man } \\
\text { Hr. }\end{array}$ & \\
\hline $\begin{array}{c}\text { Type } \\
\text { A }\end{array}$ & 15 & 70 & 20 & 2 & 140 & 10,000 \\
\hline $\begin{array}{c}\text { Type } \\
\text { B }\end{array}$ & 27 & 120 & 36 & 4 & 252 & 18,000 \\
\hline $\begin{array}{c}\text { Type } \\
\text { C }\end{array}$ & 45 & 200 & 60 & 6 & 420 & 30,000 \\
\hline
\end{tabular}

Let number of Shops of type A =w1

Let number of Shops of type B =w2

Let number of Shops of type $\mathrm{C}=\mathrm{w} 3$

Let $\mathrm{Z}$ represent the total profit to be maximized.

The linear programming problem for the above data is given by
Maximize $Z=10000 w 1+18000 w 2+30000 w 3$

Subject to

$$
\begin{array}{ll}
15 w 1+27 w 2+45 w 3 & \leq 7800 \\
70 w 1+120 w 2+200 w 3 & \leq 35,000 \\
20 w 1+36 w 2+60 w 3 & \leq 10,000 \\
2 w 1+4 w 2+6 w 3 & \leq 11,000 \\
140 w 1+252 w 2+420 w 3 & \leq 70,000 \\
w 1 \geq 100 & \\
w 2 \geq 50 & \\
\text { w3 } \geq 50 & \\
\text { and } w 1, w 2, w 3 \geq 0 &
\end{array}
$$

Using slack and surplus variables (Arsham (1997)),the problem converted to

\section{Maximize}

$\mathrm{Z}=10000 \mathrm{w} 1+18000 \mathrm{w} 2+30000 \mathrm{w} 3+0 . \mathrm{s} 1+0 . \mathrm{s} 2+0 . \mathrm{s} 3+0 . \mathrm{s} 4+0 . \mathrm{s} 5+$ $0 . s 6+0 . s 7+0 . s 8$

Subject to

$$
\begin{array}{ll}
15 \mathrm{w} 1+27 \mathrm{w} 2+45 \mathrm{w} 3+\mathrm{s} 1 & =7800 \\
70 \mathrm{w} 1+120 \mathrm{w} 2+200 \mathrm{w} 3+\mathrm{s} 2 & =35,000 \\
20 \mathrm{w} 1+36 \mathrm{w} 2+60 \mathrm{w} 3+\mathrm{s} 3 & =10,000 \\
2 \mathrm{w} 1+4 \mathrm{w} 2+6 \mathrm{w} 3+\mathrm{s} 4 & =11,000 \\
140 \mathrm{w} 1+252 \mathrm{w} 2+420 \mathrm{w} 3+\mathrm{s} 5 & =70,000 \\
\mathrm{w} 1-\mathrm{s} 6 & =100 \\
\mathrm{w} 2-\mathrm{s} 7 & =50 \\
\mathrm{w} 3-\mathrm{s} 8 & =50
\end{array}
$$$$
\text { and w1,w2,w3,s1,s2,s3,s4,s5,s6,s7,s8 } \geq 0
$$

\section{EXPERIMENT AND RESULT}

The Housing-Society model is based on assumed data specified that the maximum profit of company is Rs. $33,30,000$ and number of House (Flat) of type A is 31, type B is 18 and type $\mathrm{C}$ is 10 .

Lingo software (Goodarzi et al (2014)) is applied for solving the Shopping Mall problem, we get an optimal solution as $\mathrm{w} 1=260, \mathrm{w} 2=50, \mathrm{w} 3=50$ and Maximum $\mathrm{Z}=50,00,000$.

\section{CONCLUSION}

The Shopping Mall model based on assumed data specified that the maximum profit of Company is Rs. 50,00,000 and the number of shops of type A is 260 , type $B$ is 50 and type $C$ is 50. From the discussion it is concluded that for developing housing society, the maximum profit of company is Rs. $33,30,000$ by constructing 31 house (flat) of type A,18 house(flat) of type B,10 house (flat) of type $\mathrm{C}$ and for developing shopping mall, the maximum profit of company is Rs 50,00,000 by constructing 260 shops of type A ,50 shops of each type $\mathrm{B}$ and $\mathrm{C}$. 


\section{REFERENCE}

[1] Arditi, D., Koksal, A., \& Kale, S. (2000). Business failures in the construction industry. Engineering Construction and Architectural Management, 7(2), (Pg 120-132).

[2] Arsham, H. (1997). An artificial-free simplex-type algorithm for general LP models. Mathematical and Computer modelling, 25(1), (Pg 107-123).

[3] Connie Susilawati, Desire L. Litaay, Andre Prasaulion, (2001) "Application of Linear Programming for Dormitory Development plan at Petra Christian University", DimensiTekniksipil, Vol. 3, number 2 (Pg 59-63).

[4] Dantzig, G. B., \& Thapa, M. N. (2006). Linear programming 1: introduction. Springer Science \& Business Media.

[5] Dorfman, R., Samuelson, P. A., \& Solow, R. M. (1987). Linear programming and economic analysis. Courier Corporation.

[6] Goodarzi, E., Ziaei, M., \& Hosseinipour, E. Z. (2014). Optimization analysis using LINGO and MATLAB. In Introduction to Optimization Analysis in Hydrosystem Engineering (pp. 149-193). Springer, Cham.

[7] Hendrickson, C., Zozaya-Gorostiza, C., Rehak, D., Baracco-Miller, E., \& Lim, P. (1987). Expert system for construction planning. Journal of Computing in Civil Engineering, 1(4), (Pg 253-269).

[8] Kandil, A., El-Rayes, K., \& El-Anwar, O. (2010). Optimization research: Enhancing the robustness of large-scale multiobjective optimization in construction. Journal of Construction Engineering and Management, 136(1),(Pg 17-25).

[9] Ling, Jiang,(2013) "Linear Programming Application in Construction Enterprises", Applied Mechanics and Materials, Vol. 328 (Pg 244 - 247)

[10] Mahdi, I. M. (2004). A new LSM approach for planning repetitive housing projects. International Journal of Project Management, 22(4),(Pg 339-346)

[11] Makowski, D., Hendrix, E. M., van Ittersum, M. K., \& Rossing, W. A. (2000). A framework to study nearly optimal solutions of linear programming models developed for agricultural land use exploration. Ecological Modelling, 131(1), (Pg 65-77).

[12] Oladejo, N. K., Abolarinwa, A., Salawu, S. O., \& Lukman, A. F. (2019). OPTIMIZATION PRINCIPLE AND ITS'APPLICATION

UNIVERSITY BAKERY PRODUCTION USING LINEAR PROGRAMMING. International Journal of Civil Engineering and Technology (IJCIET), 10(2), (Pg 183-190)
[13] Olawale, Y. A., \& Sun, M. (2010). Cost and time control of construction projects: inhibiting factors and mitigating measures in practice. Construction management and economics, 28(5), (Pg 509-526).

[14] Shifat Ahmed, (2015) "An Approach to Maximize profit of a constructing project within Limited Budget by using Simplex Method", International Journal of Scientific and Engineering Research, Vol. 6, Issue 11 (Pg 786-791).

[15] Wallbaum, H., Ostermeyer, Y., Salzer, C., \& Escamilla, E. Z. (2012). Indicator based sustainability assessment tool for affordable housing construction technologies. Ecological Indicators, 18, (Pg 353-364). 